\title{
Bariéry otcovských tranzícií
}

\section{Barriers within Fatherhood Transitions}

Juraj Potančok

\begin{abstract}
Men who are becoming fathers go through two main phases: the transition to fatherhood and transition(s) within fatherhood. These transitions can be perceived as changes in the realization of biological and social fatherhood. Both transitions are significant from the perspective of the construction of both a father (paternal) role and a child-focused relationship. This study examines the barriers that may interfere with, slow down, or interrupt these transitions and changes. The analysis focuses on the personal and social character of these transitions and changes. Special attention is directed toward the barriers to transition within fatherhood, as this may significantly impact the lifecycle of a child, the parent and the family.
\end{abstract}

KEYWORDS father, fatherhood, parenthood barriers

\section{Úvod}

Téma otcovstva priniesla $\mathrm{v}$ posledných rokoch množstvo štúdií zaoberajúcich sa otcovstvom ako významným fenoménom tak rodinného ako aj mimo-rodinného správania. Sociologický záujem o otcov otvoril dvere pre skúmanie širokej palety problémov a postavil muža do centra pozornosti výskumných otázok týkajúcich sa rodičovských, partnerských a profesionálnych vzt'ahov v kontexte sociológie rodiny, ako aj iných vedných disciplín. Diskusia, ktorá sa vedie na tému otcovstva, v sebe zahŕňa niekol'ko nosných tém. Tie pojednávajú o vzt’ahu tradičného a moderného chápania otcovskej roly, spoločenských očakávaniach, organizácii del'by práce v domácnosti či usporiadaní vzt’ahov a rodičovských zodpovedností po rozpade manželstva, alebo partnerstva, ktorého súčast'ou sú spoločné deti (pozri napríklad Arendell 1995; Dowd 2000; Geiger 1996; Marsiglio 1995; LaRossa 1997; Townsend 2002; Hobson 2002; Lubpton a Barclay 1997; Nock 1998; Možný 1983, 1990; Dudová 2008; Smart a Neale 1999).

Záujem o problematiku otca a otcovstva tvorí aj základný rámec predkladanej štúdie. Pohl'ad na otca je tu prezentovaný ako pohl'ad dvoch tranzičných procesov vo forme prechodu k otcovstvu a prechodov vnútri otcovstva (Palkovitz a Palm 2009). Stredobodom

Sociálni studia. Katedra sociologie FSS MU, 4/2011. S. 29-45. ISSN 1214-813X. 
výkladu ale nebudú len zmeny samotné, pozornost' sa zameria najmä na bariéry, ktoré bránia mužom v tom, aby mohli dané tranzičné procesy rozvinút', prípadne čelit' ich možným následkom. Jednotlivé kapitoly pojednajú o význame individuálnych (kapitola 3) a spoločenských (kapitola 4) determinantov brániacich mužom v ceste k otcovstvu, ako aj v adaptácii na nové situácie, ktoré sa môžu vyskytnút' od doby, kedy sa muž stane otcom.

\section{Otcovské tranzície}

Ak hovoríme o prechode, alebo o tranzícii, väčšinou máme na mysli zmenu z jedného štádia na iné. Tranzitívnost' v sebe zahŕňa istý vývoj, evolúciu, zmenu z jednej formy usporiadania na inú, alebo akceptáciu nových elementov, ktoré menia vnímanie už zažitej sociálnej reality. Tento proces naznačuje vychýlenie z rovnováhy každodennej, opakujúcej sa skúsenosti a snahu o jej opätovné nadobudnutie. K tranzícii v živote jednotlivca alebo spoločnosti môže dôjst' vtedy, ked' sa vyskytnú nové výzvy a okolnosti, ktoré významne zasahujú do bežného života (Palkovitz a Palm 2009: 4). V živote jednotlivca môže medzi také okolnosti patrit' napríklad ukončenie školy a hl'adanie si práce, prepustenie z práce, sobáš, rozchod či rozvod. Do týchto zmien je možné zahrnút' aj vážnu chorobu, st’ahovanie sa a vytváranie nového domova a pod. V kontexte otcovstva a rodičovstva je takouto okolnost'ou počatie a narodenie diet'at'a.

V sociálnej psychológii, Palkovitz a Palm (2009) d’alej uvádzajú, je tranzícia chápaná ako zmena odohrávajúca sa na troch úrovniach: kognitívnej, afektívnej a behavioralnej. Ak obrátime pozornost' na muža, tak počatie diet'at'a môže naštartovat' proces uvedomenia si novej situácie a okolnosti (kognitívna úroveň), jej spracovanie a prijatie (afektívna úroveň), a prispôsobenie sa cez zvolené stratégie konania (behaviorálna úroveň). ${ }^{1}$ Podobný proces prežívajú otcovia aj v neskorších štádiách života diet'at'a, čoho výsledkom môže byt' zaznamenanie zmeny v zažitej realite a štruktúre vzt’ahov rodinného usporiadania. Novonadobudnutá realita je následne spojená so zmenou v rolových očakávaniach tak samotného aktéra, ako aj jeho okolia.

\subsection{Prechod k otcovstvu}

Prechod k otcovstvu (ako aj prechod k materstvu u ženy) možno všeobecne považovat' za významný zlom v živote muža, pretože prináša zmenu vnímania muža a jeho postavenia v spoločnosti. Táto zmena sa prejavuje napríklad v zmene rolových očakávaní zo strany samotného muža-otca, jeho partnerky, narodeného diet’at'a či spoločnosti. Je preto namieste si položit' základnú otázku: kedy sa muž stáva otcom? Ktorý moment/udalost' mení naše vnímanie muža tak, že ho môžeme považovat' za otca? Je viacero pohl'adov na to, od ktorého

Samozrejme to platí aj pre prípad ženy matky, ktorej sa to tiež týka, a preto by nemala byt' z tejto diskusie vynechaná. Zmeny v živote ženy sú umocnené o to viac, že sú prepojené s biologickými predpokladmi materstva (tehotenstvo, kojenie), ktoré muž otec prežíva len sprostredkovane cez skúsenost' partnerky. Problematiku tehotenstva napríklad rozviedla Jaroslava Hasmanová Marhánková (2009). 
okamihu považujeme mužov za otcov. Z biologického hl'adiska by k tomuto označeniu mohlo dôjst' už v momente oplodnenia, čiže biologickej koncepcie. Marsiglio (2004) s istou dávkou vtipu naznačuje, že k tomu môže dôjst’ už pri vyslovení vety „som tehotná“. Toto zistenie ale nezaručuje, že sa diet'a naozaj narodí, pretože tehotenstvo najmä vo svojej rannej fáze je vystavené vel'kému riziku. Moderná medicína v posledných rokoch síce prešla významným rozvojom v zdravotnej starostlivosti o diet'a pred jeho narodením aj tesne po ňom a dokáže diagnostikovat' a riešit' možné komplikácie, mieru potratovosti (samovol’nej, alebo umelej) však nie je možné úplne eliminovat'. ${ }^{2}$

Treba zdôraznit', že biologická informácia, ktorou sa muž podiel'a na počatí, nie je jediným aspektom, ktorý je potrebné brat' do úvahy pri procese označenia muža za otca ako aj prechodu k otcovstvu. Nakoniec dokazujú to aj rôzne antropologické štúdie (pozri Skupnik 2010). Odlišným aspektom je aspekt sociálny; ide o spôsob, akým muž otec prejavuje svoju prítomnost' v živote diet'at'a. Prítomnost' otca v živote diet'at'a sa môže prejavit' rôznymi formami cez výchovu, hry, vytváranie vzt’ahu, ale aj bežnú starostlivost', pocit bezpečia a ochrany či finančné zabezpečenie. Populárny a odborný diskurz v súčasnosti poukazuje na dôležitost' aktívneho zapojenia muža do života diet'at'a a do každodennej starostlivosti cez vzájomnú interakciu a záujem o zdiel'anie emócií. Snaží sa o prepojenie na prvý pohl'ad konfliktných strán, finančného zaopatrenia (cash) a starostlivosti (care) o diet’a (pozri Hobson a Morgan 2002).

\subsection{Prechod vnútri otcovstva}

Spôsob, akým sa otec prejavuje v praxi pri výkone otcovstva/otcovskej roly, záleží od spôsobu, akým vníma seba, a od toho, ako je jeho osobná identita prepojená s rodičovstvom, teda či je súčast'ou jeho životných záväzkov (Smart a Neale 1999: 51). Otcovstvo nie je možné vnímat' ako fenomén, ktorý má statický charakter, ako istú znalost' alebo zručnost', ktorú sme získali v príprave na otcovstvo. Otcovstvo sa dynamicky vyvíja. Rola otca sa mení nielen z generácie na generáciu, ale aj individuálne v živote jednotlivca. Každý muž-otec vníma nové podnety a mení svoju skúsenost' cez svoju individuálnu životnú trajektóriu, cez trajektóriu života diet’at'a (batol’a, predškolský vek, školský vek, puberta, dospelost' a pod.) a cez zmenu spoločenských očakávaní a módnych trendov vo výchove. Vývoj vnútri otcovskej roly je na rozdiel od prechodu k otcovstvu nekončiaci proces. Prechod k otcovstvu znamená nerevokovatel'nú skutočnost'; tým že sa muž stal rodičom a otcom, prijal na seba doživotný záväzok spojený s istými očakávaniami, ktoré sú prítomné, či rolu otca vykonáva alebo nie (Možný 1990). Prechod vnútri otcovstva znamená vývoj sociálneho aspektu otcovstva, vývoj vnútri danej roly. Každý muž-otec si tak sám konštruuje (Dudová 2008) vlastnú

\footnotetext{
Bližšie k potratovosti v ČR: <http://www.czso.cz>

Sociálne otcovstvo sa často oddel'uje od biologického a dáva do súvislosti s náhradným alebo nevlastným rodičovstvom. Výkon otcovskej roly inou osobou, ako je biologický rodič, nie je v dnešnej spoločnosti fenomén nový, alebo neštandardný, najmä ak vezmeme do úvahy mieru rozvodovosti a uzatvárania opakovaných manželstiev. Problematiku nevlastných otcov ako samostatný fenomén podrobne popísal cez výsledky výskumu napríklad William Mariglio vo svojej knihe Stepdads. Stories of Love, Hope and Repair (pozri Marsiglio 2004).
} 
trajektóriu otcovskej roly, na základe nových skutočností, ktoré sa pri výkone tejto roly vyskytnú.

Tranzíciám/prechodom vnútri otcovstva podl’a Palkovitz a Palm (2009) predchádzajú rôzne spúšt’ače (triggers), ktoré iniciujú zmenu. Podl'a autorov existuje pät’ špecifických spúšt’ačov: 1) rozvoj diet'at'a, ktorý môže byt' tak predvídatel'ný, ako aj neočakávaný, a je úzko prepojený so životnými cyklami diet’at'a; 2) rodinná kriza, ktorá sa vyskytuje v rôznych formách od separácie, rozvodu, cez fyzický či mentálny postih rodinného príslušníka, alebo zmenu rozvrhov a príjmu; mení celý systém usporiadania rodiny; 3 ) individuálna zmena u otca, ktorá sa môže prejavit' v podobe zmeny vzdelania, povýšenia v práci, choroby a pod.; 4) proti-tranzičné zmeny (counter transitional changes), ktoré súvisia so zmenami v životoch blízkych a pôsobia na vzájomný vzt'ah ako aj zainteresovanost' otca v živote detí a prejavujú sa cez priamu interakciu s nimi; napríklad odst'ahovanie diet'at'a z rodinného domu, jeho svadba a pod.; 5) historické zmeny, ktoré obsahujú širší spoločenský kontext odohrávajúci sa nad rodinou a rodinu externe ovplyvňuje; takými sú napríklad vojny, ekonomická depresia, nešt’astia, bankrot alebo zatvorenie tovární: v tomto bode autori zohl'adňujú sociálne, politické ako aj ekonomické zmeny, ktoré pôsobia ako spúšt’ače tranzície individuálnych trajektórii otcovstva.

Otcovstvo ako osobná skúsenost' jednotlivca sa týka podstatnej časti mužskej dospelej populácie. Muža môže otcovstvo sprevádzat' väčšinu jeho dospelého života, môže ho značne regulovat', alebo ho môže postavit' pred nové skutočnosti, výzvy a očakávania. Otcovstvo môže na muža pôsobit' limitujúco (potreby rodiny kladie pred osobné potreby) ale aj inšpirujúco (vedie k väčším výkonom, napríklad v práci).

V nasledujúcich kapitolách nahliadneme na bariéry, ktoré stoja v ceste otcovských tranzícií. Tieto bariéry budú predstavené v dvoch vzájomne prepojených líniách, na kontínuu od prechodu k otcovstvu k prechodu vnútri otcovstva a na kontínuu od vzniku rodiny až po jej zánik.

\section{Bariéry otcovských tranzícií}

Predchádzajúci text poukázal na to, že rodičovstvo a otcovstvo je potrebné vnímat' ako vel'kú zmenu v živote jednotlivca, ktorá spúšt’a tranzičné procesy adaptácie na novú realitu. Ich výsledkom je snaha o nadobudnutie rovnováhy (Palkovitz a Palm 2009) z nerovnovážneho stavu, ktorý bol spôsobený zmenou (rodičovstvo) zažitej reality každodennosti, a to cez uvedomenie si danej skutočnosti, prispôsobenie sa a cez nové konanie v nadobudnutej roly rodiča/otca. Uvedomenie a prispôsobenie zároveň upravuje trajektóriu života jednotlivca cez kontext nových individuálnych a spoločenských očakávaní. Činitele, ktoré bránia jednotlivým tranzičným procesom a stoja $\mathrm{v}$ ceste tak prechodu $\mathrm{k}$ otcovstvu, ako aj vývoju vnútri otcovskej roly, budú d’alej v texte považované za bariéry tranzičných procesov.

\subsection{Biologická plodnosł}

Kde tie všetky deti sú? pýta sa Ladislav Rabušic (2001) a v knihe s rovnomenným názvom rozoberá vývoj pôrodnosti v sociologickej perspektíve v Českej republike. Zamýšl’a sa nad príčinami výrazného poklesu počtu detí a na základe demografických ukazovatel'ov v Českej republike hl'adá odpoved' na otázku, prečo sa rodí čoraz menej detí. Ako uvádza, 
plodnost' (fertilita) sa skladá z dvoch rozdielnych zložiek, biologickej a sociálnej (tamtiež). Hoci sa Rabušic zaoberá predovšetkým vplyvom druhej zložky, ktorej význam, ako ukážeme nižšie, je klúčový aj pre túto štúdiu, je potrebné sa najskôr pristavit’ pri bariérach, ktoré môžu bránit' biologickej plodnosti.

Zmena v životnom štýle, v postojoch a očakávaniach má za následok aj posúvanie rozhodnutia počat' diet'at'a do čoraz vyššieho veku. Tento fenomén súvisí aj s problematikou porúch plodnosti páru. Ukazuje sa, a rastúci počet štúdií venujúcich sa tejto téme to potvrdzuje, že daný problém má aj významné sociologické implikácie (pozri napríklad Hašková 2009; Slepičková 2009, 2010; Slepičková a Fučík 2009).

Biologickú ne/plodnost' ako bariéru otcovskej tranzície možno vnímat' cez neplodnost' jeho a neplodnost' jej (Slepičková 2009). Mužská a ženská ne/plodnost' spolu súvisia a sú významne prepojené. Na mužskú neplodnost' v posledných rokoch často upozorňuje aj Svetová zdravotnícka organizácia (WHO) ako na závažný problém. Rast výskytu androgénnych príčin a ich podiel na neplodnosti páru významne zasahuje do procesu prechodu k otcovskej roly. Tento zásah môže byt' vnímaný o to problematickejšie, že mužské poruchy plodnosti sa skoro vôbec liečit' nedajú a ich výsledok sa pre muža stáva „obtížně zvratitelným verdiktem“ (Slepičková 2009: 189). Cesta k biologickému otcovstvu ako prejavu reprodukčnej stratégie muža v párovom vzt'ahu môže byt' preto vel'mi t'ažko priechodná. Potenciálne následky pre muža tak implikujú významnú psychologickú zmenu. Ako uvádza Bourdieu, „[n]edosažitelný ideál virility ${ }^{4}$ se tím snadno mění v princip nesmírné zranitelnosti“ (2000: 48). Táto zranitel'nost' sa môže prejavit' napríklad v zmene postoja $\mathrm{k}$ alternatívnemu riešeniu rodičovstva ako aj zmene vo vyjednávacej pozícii v štruktúre rodiny a párového vzt’ahu, pričom nie je vylúčená aj absolútna strata tejto pozície.

Výskum v sociálnych vedách, ktorý sa zaoberá problematikou plodnosti, skúma aj postoje a ochotu mužov a žien podiel'at' sa na riešení neplodnosti páru. Ochota podstúpit' vyšetrenie, prístupnost' formám asistovanej reprodukcie, ako aj samotná hodnota diet'at'a boli rozpracované aj v kontexte českej spoločnosti (pozri Hašková 2009, Slepičková 2009, Slepičková a Fučík 2009). Sociologická analýza „Rodina, práce a reprodukční strategie v České republice“ (Slepičková a Fučík 2009) poukázala na závislost' medzi náklonnost’ou respondentov $\mathrm{k}$ technikám asistovanej reprodukcie a demografickými ukazovatel'mi dosiahnutého vzdelania a náboženského vierovyznania. ${ }^{5}$ Stratégie asistovanej reprodukcie na jednej strane dávajú nádej párom, ktoré riešia problém poruchy plodnosti a chcú počat' diet’a, na strane druhej však menia tradičné chápanie biologického rodičovstva (materstva ako aj otcovstva). Vplyv a pokrok v medicínskom výskume tak re-definuje vzt’ahy v rodinnom

$4 \quad$ Virilitu chápe Bourdieu ako schopnost' sexuálnej a sociálnej reprodukcie (porovnaj Bourdieu 2000: 48).

5 Väčšia otvorenost' $\mathrm{k}$ týmto stratégiám sa prejavovala u respondentov s vyšším vzdelaním. Autori tiež popísali súvislost' príslušnosti $\mathrm{k}$ cirkvi a náboženského vierovyznania $\mathrm{s}$ náukou a oficiálnym odmietaním praktík umelého oplodnenia, ktoré pôsobia na formovanie postoja veriacich k týmto stratégiám. Zaujímavou skutočnost'ou bolo nepreukázanie súvislosti s vekom. Autori článku ešte poukázali na vzájomnú interakciu medzi partnermi a vplyv na formovanie postoja toho druhého v prospech stratégií asistovanej reprodukcie. Partneri v tejto interakcii pôsobili skôr ako pasívni prijímatelia, než aktívni hráči v partnerskom vyjednávaní (bližšie porovnaj Slepičková a Fučík 2009). 
usporiadaní. „Léčba využívající genetický materiál dárců [...] překrývá a odděluje různé typy rodičovství (biologické, genetické, sociální, substanční), zpochybňuje mužskou a ženskou reprodukční roli a pokrevní podstatu otcovství nebo mateřství nahrazuje smluvním vztahem“ (Slepičková 2009: 178).

Medikalizácia problému má aj širší kontext, akým je kontext partnerského vyjednávania vo vzájomnom vzt’ahu. Nejedná sa len o samotné podstúpenie techník asistovanej reprodukcie zo strany páru, alebo o zmenu životného štýlu, ktorý môže napomôct' k zvráteniu „diagnózy“ páru, skúmaný kontext sa d’alej zamotáva, ked’ zohl'adníme vplyv tretích strán. Do hry vstupujú lekári, ktorí majú moc regulovat' proces liečby cez odporúčania, vyšetrenia ako aj samotnú liečbu, ale aj štát, ktorý reguluje legislatívu asistovanej reprodukcie a určuje financovanie liečby (pozri Slepičková 2009). V neposlednom rade nemožno opomenút' postoj širšieho okolia rodiny, priatel'ov a známych k asistovanej reprodukcii ako forme riešenia biologickej plodnosti a ich vplyv a podporu takého riešenia.

\subsection{Intimita a intímne rodičovstvo6}

Schopnost' počat' diet’a je len malým čriepkom v ovel'a zložitejšej mozaike vzt'ahov, ktoré pôsobia na reprodukčné správanie jednotlivých členov rodiny. To, akým spôsobom sa muž stavia k rodičovstvu (počatie diet’at’a nevynímajúc), akým spôsobom rodičovskú rolu vykonáva, je dané širokým kontextom rôznych vplyvov. Už som naznačil vyššie, že do hry vstupuje najmä množstvo očakávaní (kultúrnych, spoločenských, individuálnych), ktorých váha a vplyv významne určujú možnost' formovat' otcovskú identitu a trajektóriu a sú vo vzt'ahu s postojmi, presvedčením a konaním muža otca.

Samotné chápanie rodiny, vnímanie jej vnútornej dynamiky a štruktúry, pôsobí na to, ako je diskurz o rodine a v rodine tvorený. Smart a Neale (1999) poukazujú na skutočnost', že existencia prílišnej diverzity vo vnímaní rodiny vylučuje možnost' hovorit' o rodine ako o homogenizujúcom koncepte. Ako d’alej uvádzajú, súčasné teórie zamerané na rodinu (napríklad teória Giddensa) používajú pojem „rodina“ len vel'mi obmedzene. Vychádzajúc z konceptu Davida Morgana a jeho pojmu „rodinné praktiky“ (family practices), Smart a Neale namiesto o rodine hovoria o súbore vzt'ahov, ktoré sa menia, pričom dôraz sa kladie na premenlivost' (fluiditu) (1999: 21). Kvalita a hĺbka vzt'ahu otvára priestor demokratizujúcim tendenciám, ktoré vyzdvihujú nielen ,právo na slobodný a rovný rozvoj jednotlivca, ale taktiež konštitučné obmedzenie (rušivej) moci“ (Giddens 1992: 186).

Vyzdvihovanie individuality a nezávislosti jednotlivca $\mathrm{v}$ rodine spôsobuje odklon od parsonsovských inštrumentálnych funkcií jednotlivých rol v systéme rodiny. V rodine

6 Problematika intimity vo vzt'ahu $\mathrm{k}$ reprodukcii bola popísaná už v samostatnom monotematickom čísle Sociálnich studií 4/2009. Za zmienku stojí najmä esej francúzskeho sociológa François de Singly (2009), ktorá prepája intimitu individuálnu a rodinnú s vývojom v chápaní osobného priestoru, ktorý sa podiel’a na budovaní osobnej identity. Svoju úvahu rozvíja na príklade vlastníctva vlastnej izby u dospievajúcich detí. 
neskorej modernity je základom „,̌istý vzt’ah“7 (Giddens 1992) založený na intimite. Intimita pre Giddensa znamená prísl'ub rovnosti a demokracie a je súčast'ou toho, čo nazýva „reflexívny projekt seba“ (the reflexive project of self) (Giddens 1991, 1992). Intimita sa pri tom netýka len partnerského vzt'ahu, ale mala by byt' súčast'ou aj nami sledovaného vzt'ahu rodič-diet’a. Lynn Jamieson (1998) vníma intimitu cez odkrývanie (disclosing intimacy) informácií, ktoré l’udia medzi sebou zdiel'ajú pri rozhovore, vyjadrovaní názorov a pocitov. Autorka vyjadruje pochybnost' voči Giddensovmu „optimistickému“ nazeraniu rovnosti a demokracie vo vzt'ahu, pretože rovnost' z pohl'adu moci je otázna najmä čo sa týka vzt'ahu medzi rodičom a nedospelým diet'at'om.

Esther Dermott vo svojej práci Intimate Fatherhood (Intímne otcovstvo) upozorňuje, že základný problém pri štúdiu intimity vo vzt’ahu k otcovstvu nie je to, „či otcovstvo má byt' konceptualizované ako forma intimity, ale to, ako je intimita vykonávaná súčasnými otcami““ (2008: 2). Tu sa ale otvára priestor pre vznik bariér otcovských tranzícií. Tie vznikajú z protichodnými očakávaniami od otcov. Už bolo naznačené, že čistý vzt'ah je vzt’ahom, ktorý je charakterizovaný intimitou a je vzt’ahom nestálym a krehkým (Giddens 1992). Intimita definovaná blízkost'ou a vzájomným zdiel’aním a odkrývaním informácii navyše vyžaduje rovnost', ale vzt'ah medzi rodičom a diet'at'om je najmä v detstve a dospievaní vzt'ahom moci a nadvlády rodičov nad det'mi (Jamieson 1998). Blízkost', ako upozorňuje Dermott (2008), sa ale pohybuje na tenkom l'ade spoločenskej akceptovatel'nosti. Muži, tvrdí Dermott, zápasia s bariérou spoločnosti, ktorá na jednej strane vyžaduje budovanie blízkeho vzt’ahu s diet'at’om, no na strane druhej pozorne sleduje, či vzt’ah nie je ,príliš“ blízky a nepresahuje hranice toho, čo je považované za akceptovatel'né.

\section{Problematický kontext vzfahov otcovských tranzícií}

Otcovia sú pri svojich tranzíciách vystavení nutnosti vyrovnat' sa s viacerými komplikovanými vzt’ahmi. Tri z nich sa pokúsim priblížit' v tejto kapitole. Zameriam sa na komplikovaný vzt'ah k živitel'skej roly (cash), komplikovaný vzt'ah k roly opatrovatel'a (care) a komplikovaný vzt’ah páru.

\subsection{Komplikovaný vztah ku „cash“}

Pri kladení dôrazu na osobnú prítomnost' muža vo výchove a starostlivosti o diet’a, ako aj na snahu vytvárat' osobný vzt'ah $\mathrm{k}$ diet’at'u, ktoré možno pozorovat' v koncepte nového otca ${ }^{8}$ sa akoby zabúdalo na ekonomickú rolu muža a úlohu platenej práce/zamestnania

7 Čistý vzt’ah sa podl’a Giddensa vzt’ahuje na situáciu, v ktorej jednotlivci vstupujú do sociálneho vzt'ahu kvôli vzt'ahu samotnému a kvôli tomu, čo môžu odvodit' z udržiavanej vzájomnej asociácie, a na situáciu, v ktorej je vzt’ah udržiavaný len dovtedy, pokial' poskytuje obom partnerom dostatok uspokojenia, aby v ňom pokračovali (Giddens 1992: 58).

8 Koncept „nového“ otca sa zameriava na snahu zviditel'nit' potrebu prítomnosti otca v rodine a živote detí aj mimo rolu živitel’a. Dôraz sa kladie na aspekt sociálneho otcovstva. „Nové“ otcovstvo sa často kladie do protikladu k ,tradičnému“ otcovi (pozri bližšie Potančok 2010). 
v jeho živote. Dermott na túto skutočnost' správne poukazuje a upozorňuje, že ,je omylom sa domnievat', že intímna a emocionálna sféra pôsobí oddelene od finančnej“ (2008: 25). Rodinná jednotka je, tvrdí Dermott, predovšetkým jednotkou založenou na rozpočte, ktorý počíta tak $\mathrm{s}$ istými výdavkami ako aj príjmami. A jedným zo základných kameňov vzt'ahu medzi rodičom a diet'at'om je práve aj finančné zaopatrenie (Dermott 2008: 26). Koncept nového otca nie je, podl'a Dermott, možné vnímat' mimo ekonomickú sféru a rolu živitel'a.

Dudová (2008), vychádzajúc z výskumu otcovstva po rozvode v Českej republike, prináša podobný záver. Poukazuje na skutočnost', že aspekt práce hrá v živote mužov dôležitú úlohu, pretože tvorí významnú súčast' otcovskej identity. Živitel'ská rola ako jeden z najvýznamnejších repertoárov budovania otcovskej identity je dodnes vnímaná otcami, ale aj v širšom spoločenskom kontexte, ako samozrejmá súčast' povinností muža - otca v rodine. Otcovia vnímajú živitel'ský repertoár ako neoddelitel'nú súčast' svojho postavenia v štruktúre rodiny. Od živitel'ského repertoáru odvíjajú následne d’alšie, ktorými konštruujú a dopíňajú rolu otca. Princíp „hlavy rodiny“, ktorá sa stará o finančné/ekonomické zabezpečenie jej členov, je u mužov implicitne prítomný, nehl'adiac na to, či sa jedná o jediný príjem v domácnosti alebo len súčast' (väčšia/menšia) celkového rodinného rozpočtu. Dudová nevidí tento vzt'ah komplementárne tak, ako ho vidí Dermott, ale skôr ako vzt’ah konfliktný. Ako tvrdí, otec môže det'om poskytnút' dva základné zdroje, ktoré sú na sebe vzt'ahovo závislé, peniaze a čas. V prípade, že dôjde k rastu na strane jedného zdroja, automaticky dochádza k poklesu na strane zdroja druhého (Dudová 2008: 47).

Problematickost' vzt’ahu ku „cash“ je potom možné vidiet' v dvoch rovinách, v prípade prílišnej snahy zapojit’ sa do starostlivosti a prílišnej pracovnej exponovanosti. Prvý príklad sa vzt’ahuje k prípadu stratenej legitimácie (Možný 1983). Podl’a Možného má väčšina žien a mužov k radikálnej zmene del'be práce v domácnosti, ktorá vyžaduje vyrovnané rozdelenie povinností, do istej miery ambivalentný postoj. Tento postoj vychádza z tradičného predpokladu rozdelenia sfér, kde domácnost' je doménou ženy. Tá je síce potešená prípadným záujmom muža ju odbremenit', najmä ked' je sama pracovne vyt'ažená, ale to len do istého bodu, ktorým je snaha muža prevziat' rozhodovanie v tejto sfére do vlastných rúk. Možný tvrdí, že ide o fenomén hlboko zakorenený v elementárnych kultúrnych štruktúrach a medzigeneračný posun je v tomto prípade nepatrný (Možný 1983: 23).

Druhý príklad, uvádza Možný, súvisí s problémom pracovne exponovanej rodiny, v ktorej obaja partneri zastávajú dobre platené miesta s možnost'ou kariérneho postupu. Snaha o symetrické rozdelenie del'by práce v procese partnerského vyjednávania tak často končí vychýlením tohto zámeru na základe množstva racionálnych ako aj iracionálnych dôvodov. Jedným z dôvodov je ekonomické zabezpečenie domácnosti. Muž tým, že neostáva doma s novonarodeným diet'at'om, neprerušuje svoje angažovanie sa v pracovnom procese a častejšie sa vydáva na cestu kariéry, ktorej venuje podstatne viac času ako žena. Žena naopak tým, že dočasne opúšsta svoje pracovné pozície kvôli materstvu, venuje viac času starostlivosti o diet’a/deti a domácnost'. Pracovne exponovaný muž, na rozdiel od predošlého príkladu, tak zápasí s dilemou medzi kvantitou času venovaného diet'at'u/det'om a jeho kvalitou. 


\subsection{Komplikovaný vziah ku „care“}

Zmenu vo vnímaní dôležitosti starostlivosti (care) spojenú s konceptom nového otca je možné vnímat' $v$ spojitosti so zmenou vnímania kvality vzt'ahu rodiča $\mathrm{k}$ diet'at'u/diet'at'om a v spojitosti so zmenou postavenia diet'at'a v súčasnej rodine. $\mathrm{K}$ zmene pohl'adu na diet'a došlo $\mathrm{s}$ jeho presunutím do centra záujmu rodiny, čo následne spôsobilo transformáciu chápania významu slova rodič. Phillipe Ariès v tomto kontexte uvádza nový koncept detstva, „, k ktorom sa diet'a $\mathrm{z}$ dôvodu svojej roztomilosti, jednoduchosti a utešenosti stalo pre dospelého zdrojom rozptýlenia a oddychu“ (Ariès 1962: 128). Navyše, ako poznamenáva François de Singly, prechod od „starej“ rodiny k „modernej“ sa udial cez meniaci sa vzt'ah s diet’at'om (Singly 1999: 22).

Literatúra venujúca sa konceptu nového otca, ktorý je opatrovnícky (Marsiglio 2004), starostlivý (Gaiger 1996), generatívny (Erikson 2002), no najmä prítomný (Forste, Bartowski a Jackson 2009), vníma otca ako muža, ktorý má pozitívny vzt’ah ku „care“. Orientácia na blízky, intímny vzt'ah s diet’at’om v tomto kontexte vytvára dichotomické rozdelenie na „dobrého“ a „zlého“ otca (Furstenberg 1995). Zmena konceptu v podobe odklonu od ,poskytovat““ (provide for them) a príklonu k „byt' prítomný“ (be there for them), mení tradičnú predstavu a kultúrne vnímanie otca ako toho, ktorý „vládne svetu“9 (Dinnerstein 1999), a usiluje o jeho zapojenie do diania vnútri rodiny. Intimita, zdiel'anie a starostlivost' sa v tomto koncepte stávajú základnými znalost’ami a schopnost’ami, podl’a ktorých sa meria moderný muž-otec na škále dobrý - zlý a ktoré ho legitimujú ako vzorový, ideálny príklad otca (Marks a Palkovitz 2007, Marsiglio 1995, Furstenberg 1995).

Muži sa dostávajú do ambivalentnej pozície aspoň z pohl'adu tradične vnímanej mužskej roly, pretože tá predpokladá istú odlišnost' od roly ženy-matky, aby sa mohla naplnit' komplementarita rolí (Možný 1990, Šmídová 2002). Podl’a Možného dochádza k miešaniu tradičnej a egalitárnej filozofie vo sfére starostlivosti o deti, ktorá sa prejavuje cez ,tichý spor o roli

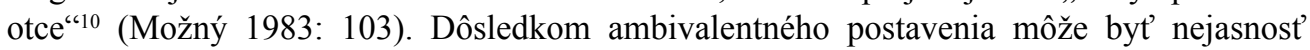
otcovskej roly (Beck-Gernsheim 2002, Marsiglio 1995, Daly 1995, Hobson a Morgan 2002).

Komplikovaný vzt’ah ku „care“ je ovplyvnený aj schopnost'ou využitia času, ktorý má muž otec $\mathrm{k}$ dispozícii na interakciu s diet’atom. Ako bolo uvedené vyššie, dilema kvantity a kvality pre pracovne exponovaného muža (no nielen pre muža) môže spôsobit' nakumulovanie emocionálnych zážitkov do obmedzeného krátkeho časového výseku dňa (napríklad po pracovnej dobe, počas víkendu). Jeho využitie na vytvorenie blízkeho vzt'ahu s diet’at’om a budovanie vzájomnej intimity cez zapojenie sa do aktívnej interakcie a výchovy môže byt' ovplyvnené vytvorenými bariérami vo vzt'ahu medzi otcom a diet'at'om (napríklad cez odmietanie tohto vzt'ahu zo strany diet'at'a, alebo neschopnosti otca tento vzt'ah nadviazat').

9 Dinnerstein (1999) používa metaforu toho, kto „hojdá kolísku“ a „vládne svetu“, na popis del’by práce, ktorá je asociovaná s tradičnou rodinou, kde muž reprezentuje prepojenie s vonkajším svetom (vládnutie svetu) a žena reprezentuje vnútorný svet rodiny (hojdanie kolísky).

10 Tento spor sa prejavuje podla Možného nasledovne: „[a]čkoli je podle důsledně egalitární filozofie otec pro dítě naprosto stejně důležitý jako matka a matka očekává od něho při výchově dítěte a v péči o dítě podíl práce a výkon činností, které byly podle tradiční filozofie neslučitelné s mužstvím, prece jenom na druhé straně usiluje o to, aby i v této sfére (zejména u malých dětí) dominovala“" (Možný 1983: 103). 


\subsection{Komplikovaný vzlah páru}

Sociologická literatúra popisujúca štruktúru vzt’ahov v rodine poukazuje na to, že vzájomný vzt'ah otca a detí je často významne závislý od intervencie matky. Matka je vnímaná ako hlavný činitel', ktorý sprostredkováva a umožňuje existenciu a pokračovanie tohto vzt’ahu (Možný 1990, Dudová 2008, Devault a kol. 2008). Súčasná rodina s oboma rodičmi, píše Možný, má „za základ svého půdorysu vztah matka dítě, k němuž vytváŕí otec důležitou, nicméně až třetí komponentu, a platí to nejen v raném dětství, ale i v adolescenci, tedy pořád“ (Možný 1990: 107). Nadviazanie rodičovského intímneho vzt'ahu otca s diet’at'om preto často závisí práve od kvality vzt'ahu otca s matkou.

Vzt’ah páru v súčasnej rodine možno vnímat' cez proces, ktorý Giddens $(1991,1992)$ nazval transformáciou intimity (transformation of intimacy). Podl'a Giddensa preniesla zmena vnímania muža a ženy $\mathrm{v}$ partnerskom vzt'ahu váhu $\mathrm{z}$ aspektu reprodukcie na aspekt nazerania párového vzt’ahu ako vzt'ahu spolupracovníkov v ,spoločnom citovom podniku“ (joint emotional enterprise), ktorý je nadradený aj záväzkom rodičov voči det’om (Giddens 1992: 26). Hoci uvedené tvrdenie ide na prvý pohl'ad proti vnímaniu väzby matka-diet’a ako základnej, toto zdanie sa rozplynie hned', ako do hry vstúpi Giddensovo vnímanie čistého vzt’ahu a splývavej lásky, ${ }^{11}$ ktoré významne re-definujú partnerské spolunažívanie a stabilitu vzt'ahu. Muž môže vnímat' vzt'ah medzi matkou a diet'at'om ako ohrozenie prvenstva spoločného citového podniku, ktorý sa snaží vytvárat' cez intimitu so svojou partnerkou. ${ }^{12}$ Pôsobia tu tak dve sily: strach otca o vzt'ah s matkou a ochota matky sprostredkovat' vzt'ah medzi otcom a diet'at'om. Čistý vzt'ah podl'a Giddensa vyžaduje od oboch partnerov plnú účast' (emocionálnu a fyzickú), zároveň však v prípade nespokojnosti dáva možnost' sa z tohto zväzku jednoducho vyviazat'.

Vzt'ah s matku a jeho komplikovanost' $\mathrm{v}$ kontexte rodičovstva a sprostredkovania vzt'ahu otca s diet'at'om je preto možné najjasnejšie vidiet' pri rozpade rodinnej jednotky, ktorej súčast'ou sú deti. Celý mikrosvet partnerských interakcií a očakávaní prechádza pri rozpade rodinnej jednotky významnou rekonštrukciou, ktorej úlohou je nielen re-definovanie partnerského vzt'ahu, ale aj určenie hraníc rodičovských interakcií s diet’at’om/det'mi. Problém pre mužov-otcov nastáva najmä vtedy, ak muž až po rozpade rodinnej jednotky nadobúda Eriksonove štádium generativity ${ }^{13}$ (Chorvát 1999). Inými slovami, problémy spojené s rozpadávajúcim sa vzt'ahom sú umocnené v prípade, že sa muž-otec začne zaujímat' o vytváranie vzt'ahu s det'mi až po rozpade rodinnej jednotky. Komunikácia s matkou $\mathrm{v}$ takom prípade môže nielen napomáhat' pri určovaní kvality partnerskej interakcie, ale

11 Splývavá láska (confluent love) je podla Giddensa (1992) aktívnou a podmienenou láskou, ktorá pozostáva z ,na-vždy“, ,jeden-jediný“ kvalít romantickej lásky (s. 61). Predpokladá rovnost’ prijímania a rozdávania (s. 62). Taktiež predpokladá intímnost'. V prípade, že intímnost' nie je dosiahnutá, tak jednotlivec je pripravený takýto vzt’ah opustit' (s. 84). Rozchody a rozvody v dnešnej spoločnosti, tvrdí Giddens, sú skôr dôsledkom ako príčinou tejto lásky.

12 Za upozornenie na tento fakt d’akujem jednému z recenzentov tejto štúdie.

13 Erik Erikson (2002) chápe generativitu ako posledné zo siedmich štádií jednotlivca, ktorými počas svojho života prechádza. Toto štádium je charakteristické pro-kreativitou a ,potrebou byt' potrebný“. Je vyjadrené cez starostlivost' o deti a ich socializáciu. Erikson vníma generativitu ako starostlivost' o druhých, ktorá prispieva k dobru d’alšej generácie. 
aj rozsahu rodičovských kontaktov (téma rozvodu a vplyvu na zapojenie otca do výchovy po rozpade manželstva bola rozpracovaná v množstve štúdií, napríklad: Smart a Neale 1999, Arendell 1995, Geiger 1996, Hobson 2002, Lupton a Barclay 1997, Marsiglio 2004, Dudová 2008, Černá 2001).

\section{Kontext spoločenských očakávaní}

Už bolo naznačené vyššie v texte, že problematika otcovstva je ovplyvnená širším kontextom spoločenských očakávaní, ktorý vytvára a mení obsah jednotlivých sociálnych rol, otcovstvo nevynímajúc. Sociálne prostredie a kontext spoločenských očakávaní kontroluje výkon a rozvoj otcovskej roly a pôsobí na n̆u tak mimo ako aj vnútri rodiny. Do hry vstupuje viacero faktorov, ktoré sa nachádzajú na kontinuu od sociálneho postavenia, cez triednu príslušnost', výšku vzdelania, vierovyznanie, vek, ako aj vplyv médií a verejného diskurzu, sociálneho tlaku komunity či štátu a pod.

\subsection{Médiá a uniformizácia otcovstva}

Francois de Singly vo svojej práci Sociologie současné rodiny píše že, „každá sociálna skupina má svoj typ rodiny“ (Singly 1999: 97). Singlyho pluralita vnímania toho, čo je to rodina, sa podobá Morganovmu vnímaniu rodinných praktík (pozri vyššie). Túto premisu ale možno interpretovat' aj na individuálnej úrovni cez tvrdenie, že každá sociálna skupina má svoj typ otcovstva, a teda aj súbor otcovských praktík, ktoré sú špecifické pre danú sociálnu skupinu. Muž, ktorý konštruuje vlastnú rolu otca, tak preberá zároveň aj isté vzorce správania charakteristické pre otcovstvo v sociálnej skupine, z ktorej pochádza.

$\mathrm{V}$ dnešnej dobe majú čoraz viac do vývoja na poli otcovských repertoárov čo povedat' aj masové médiá, ktorých prítomnost' v každodennosti jednotlivca významne pôsobí na rebríček hodnôt, túžob, ako aj na spôsob správania (McQuail 2007). O vplyve médií nie je potrebné obzvlášt' hovorit', najmä ak si uvedomíme ich prítomnost' $v$ živote jednotlivcov a skupín. Žijeme v spoločnosti, ktorá nás zaplavuje množstvom informácií a ktorá ponúka rady na rôzne aspekty l’udského života. Úloha médií a masovej komunikácie je prítomna aj pri formovaní otcovstva a otcovskej roly vnútri jednotlivých sociálnych skupín. Prezentovanie otcovstva vo filme, seriáloch, tlači, na diskusných fórach a internetových stránkach venovaných partnerským vzt’ahom, sexu, ale aj spôsobom výchovy a receptom, ako zvládat' situácie, do ktorých sa dostáva rodič pri výchove diet'at'a, formujú priamo, alebo sprostredkovane obraz otcovstva. Móda a módne trendy vo výchove a starostlivosti o deti určujú nielen spôsoby výkonu otcovskej roly, ale aj atribúty, na základe ktorých sú muži hodnotení v rámci výkonu svojej otcovskej roly. Móda pôsobí aj na to, ako je vnímaný ideál otca, je významne prítomná pri vytváraní hodnotenia otcovstva na škále dobrý - zlý (Furstenberg 1995).

$\mathrm{V}$ súčasnosti je tak možné pozorovat' istú snahu o uniformizáciu otcovstva $\mathrm{v}$ zmysle vytvorenia jednotnej šablóny ideálneho otcovstva, podl'a ktorej sa budú posudzovat' individuálne výkony mužov otcov. Tento proces môže mat' dve príčiny: pokus eliminovat' rezíduá tradičného vnímania otcovstva založeného na dominantnom postavení muža v rodine 
a pokus presadit' egalitárny model domácnosti založený na rovnom rozdelení práce a povinností v starostlivosti o deti a domácnost'.

Tento trend však môže narážat' na praktickú realizáciu v rodine. Nejde pri tom len o odklon od modelu symetrického rozdelenia povinností, spomínaný vyššie (Možný 1983). Významný je aj konflikt medzi hodnotami a vzorcami správania u jednotlivých tried a sociálnych skupín, tj. hodnotami, ktoré jednotlivec získal v procese socializácie, a hodnotami, ktoré sú prezentované médiami. Trend unifomizácie otcovskej roly tak môže byt' jedným zo spôsobov objasnenia „,neistej“ a „hmlistej“ definície otcovstva, ktorá je prítomná v súčasnom diskurze (Beck-Gernsheim 2002, Marsiglio 1995, Daly 1995, Hobson 2002). Ostáva ale otázne, či nezohl'adnenie špecifík závislých na diverzifikovanom sociálnom postavení (Forste, Bartovski a Jackson 2009), vzdelaní či náboženskej príslušnosti nespôsobí skôr nezáujem mužov o otcovstvo.

\subsection{Odkladanie a načasovanost rodičovstva ako sociálny problém}

Kontext spoločenských očakávaní je prítomný aj pri načasovaní rodičovstva. Niektoré výskumy (La Rossa 1997, Cabrera a kol. 2000, Devault a kol. 2008) poukazujú na fakt, že obdobie vekovej vyspelosti vstupu do rodičovskej roly výrazne ovplyvňuje aj jej následný vývoj. Na jednej strane možno nájst' súvislost' s bohatost'ou životných skúseností a vedomostí; na druhej strane sa objavuje imperatív pripravenosti na vstup do rodičovstva. Trend zvyšovania veku rodičov pri narodení prvého diet'at'a zvyšuje aj šance väčšej pripravenosti rodičov na úlohu otca a matky. Odkladanie plodnosti v dôsledku študijných povinností, budovania kariéry, zážitkovej turistiky, uživania si novej fázy životného cyklu či obdobia, ktoré Možný nazýva „,dospělé mládí“14, odd’al'uje prechod k otcovstvu a rodičovstvu a niekedy mu aj zabraňuje. Tu je možné sa vrátit' ku sociálnym a kultúrnym faktorom reprodukcie (Rabušic 2001).

Snaha o správnu načasovanost' môže pôsobit' na odloženie reprodukcie do vyššieho veku a prejavuje sa vo forme odkladaného materstva (Bartošová 2009, Tomášek 2006a), a tým pádom aj odkladaného otcovstva. Odkladané rodičovstvo skracuje reprodukčné obdobie a znižuje konečnú plodnost', čiže počet detí, ktoré sa danému páru reálne narodí. Zároveň zvyšuje riziko, že tento pár zostane bezdetný, pričom ako uvádza Hašková, ,...hranice mezi dobrovolností a nedobrovolností je ve vyprávěních bezdětných často tenká, křehká, nejasná a různě překračovaná“ (Hašková 2000: 128).

Sebarealizácia a nové životné štýly ako faktory odkladania, odd’al'ovania alebo odmietania otcovstva a rodičovstva sa $\mathrm{v}$ dnešnej dobe výrazne podpisujú pod pokles plodnosti a pôrodnosti (Rabušic 2001). Rabušic túto zmenu považuje za prirodzený vývoj kultúrnej

14 „Dospělé mládí“ definuje Ivo Možný ako obdobie, v ktorom sa nachádzajú mladí l’udia „mezi dvacítkou a třicítkou, kdy jsou už dospělí, ale ještě nemají děti a mohou si užívat“. Toto obdobie dáva do kontrastu s minulost'ou, ked' mladí muži išli na prezenčnú vojenskú službu, po návrate splodili diet’a so svojou partnerkou, následne sa vzali a založili rodinu. Vek prvorodičiek v tej dobe bol 21 rokov. Viac s rozhovoru s Ivo Možným v iDnes.cz z 30. 12. 2008 „Naše doba nápadně připomína chvíle před pádem Říma“ je možné nájst' na: <www.zpravy.idnes.cz> 
premeny po roku 1989. Manželstvo a rodičovstvo už nie je univerzálne (Beck 2004) a prestalo byt' trajektóriou, ktorá je prirodzeným vyvrcholením vyjednávania na partnerskom trhu. Manželstvo a rodičovstvo sa stalo jednou z volieb (Možný 1990, Beck 2004) z množiny iných životných stratégií, ktoré sú jednotlivcovi ponúkané.

Individualizmus, ktorý prispel k vzniku individualizačného habitu (Tomášek 2006b, Bourdieu 1998), ponúka stratégie odlišné od života v rodine. Zvyšujúci sa počet l'udí, ktorí žijú ako singles alebo oddelene spolu (living apart together) a pod., zvyšuje aj počet mužov bez stratégie realizácie otcovstva. Tomášek (2007) v kontexte českej spoločnosti hovorí o ,norme praktikovanej bezdetnosti“ mužov a žien, ktorá je jednotlivcom odovzdávaná ako súčast' balíčka príručného vedenia dávno pred dosiahnutím fyzickej dospelosti. Norma praktikovanej bezdetnosti ${ }^{15}$ je nielen predmetom teoretického výkladu, ale aj praktického tréningu v rámci povinnej školskej dochádzky. Po dosiahnutí biologickej dospelosti sa stáva dominantou a pravidelne sa opakujúcou životnou skúsenost'ou, ktorá sa chápe ako zodpovedné správanie sa jednotlivcov v partnerskom vzt'ahu. Neprestáva byt' prítomná ani neskôr v partnerskom vzt'ahu po narodení diet'at'a/detí (Tomášek 2007). Navyše muži sú oslobodení od pocitu tlaku veku vo svojom reprodukčnom správaní, tak ako to býva zdôrazňované u žien cez tzv. „tikanie biologických hodín“. V prípade mužov ide o málo pravdepodobný faktor, ktorý by pôsobil pro-reprodukčne. Túžba mat' diet'a môže skôr vyrást' zo strachu z osamelosti (Beck 2004) alebo potreby po sebe niečo zanechat', ktorá sa môže objavit' v neskoršom veku.

Odkladanie, respektíve načasovanie rodičovstva, vychádza z kultúrnej zmeny, ktorá zmenila vnímanie hodnoty diet'at'a. Diet’a je chápané ako významná investícia, možno prvok prestíže, cez ktorý sa predlžuje línia rodinnej histórie. Táto investícia má zároveň dlhodobý charakter a je nezvrátitel’ná, pričom ekonomický úžitok je nahradený emocionálnym naplnením. Preto aj uvažovanie o tom, kedy, kol'ko a či vôbec mat' deti, je prepojené s uvažovaním, či je možné si diet’a finančne dovolit', či s príchodom diet'at’a nepoklesne nadobudnutý životný štandard a či bude $\mathrm{v}$ silách rodičov istý životný štandard odovzdat' splodenému potomkovi. Materiálne bariéry rodičovstva čoraz výraznejšie zasahujú pri rozhodovaní sa na ceste k rodičovstvu (Tomášek 2006a). „Př́ležitosti, které poskytuje život bez dětí, přstávají být postupně v rozhodování o založení rodiny podstatné, nebo se mění na bariéry rodičovství““ (Hašková 2009: 164).

\section{Záver: Kríza rodiny a kríza v párovej rodine}

Dôraz na individualizmus ako aj strata univerzálneho charakteru manželstva a rodičovstva zmenili nielen individuálne životné trajektórie v životoch mužov a žien, ale najmä nazeranie na nuklerárnu, párovú rodinu, ktorá je definovaná ako heterosexuálny pár vychovávajúci deti (Smart a Neale 1999). Bezdetnost' sa stáva normou (Tomášek 2007), ktorá stojí v ceste reprodukčných stratégií mužov a žien. Zmeny v reprodukčných stratégiách,

15 Praktikovanú bezdetnost' možno chápat' vo výklade Tomáška ako „zamezení otěhotnění a dětnosti““ (Tomášek 2007: 128). V jeho výklade „,norma dospělosti není svázána s rodičovstvím. [...] Reálná životní praxe, postavená na již zautomatizovaném zabraňování dětnosti, je převažující normou, at' už mluvíme o bezdětných lidech, nebo o lidech, kterým se již narodilo dítě/děti““ (s. 129). 
diverzifikácia foriem spolužitia, zmeny v demografických ukazovatel'och, ktoré oslabujú existenciu párovej rodiny, a dôraz na osobný úspech jednotlivca $\mathrm{v}$ rodine i mimo nej sa niektorými autormi reprodukuje aj ako kríza rodiny (Keller 1992, Beck 2004). Ulrich Beck v tomto kontexte uvádza:

Manželství je možné oddělit od sexuality a sexualitu opět od rodičovství, rodičovství se dá znásobit rozvodem a to vše lze vydělit společným nebo odděleným životem a mocnit několika možnými bydlišti a vždy existující možnosti revidovat svá rozhodnutí. (Beck 2004: 190)

„Krízu“ rodiny je tak možné vnímat’ ako krízu vo vzt’ahu páru. Jedným z jej najviditel'nejších prejavov je absencia otca, ktorá sa odvíja od krehkosti párových vzt'ahov. Demografické štatistiky v Českej republike napríklad dlhodobo zaznamenávajú rast rozvodovosti (skoro každé druhé manželstvo v Českej republike končí rozvodom) ${ }^{16}$, či rast počtu slobodných matiek vychovávajúcich deti bez otca. ${ }^{17}$ Zdá sa, že manželstvo a rodičovstvo prestali byt' nerozlučne prepojenými entitami rodinného života a prirodzenou stratégiou dospelosti. Oddelenie reprodukcie, ale aj partnerského spolužitia od tradične chápanej nukleárnej rodiny popri tom, že liberalizovalo trh partnerského vyjednávania (sňatkový trh), uvol'nilo aj väzby rodičovských obligácií. Tým, že je muž vyviazaný z otcovských povinností, akoby strácal aj posledné prepojenie, ktoré by ho mohlo k rodine viazat'. Oslabenie neformálnej sociálnej kontroly, ktorá v minulosti sankcionovala muža neplniaceho si svoje rodinné povinnosti, spôsobilo, že muž má k rodine ešte d'alej ako kedykol'vek pred tým.

Sociologicky významným je samotný dôvod rozpadu manželstiev. Zo štatistík vyplýva, že tri štvrtiny prípadov rozchádzajúcich sa párov tak robí z dôvodu rozdielu pováh, názorov a záujmov. ${ }^{18}$ Čo konkrétne sa za týmto všeobecným dôvodom skrýva, čísla nešpecifikujú. Je otázne, či zhoda pováh, názorov a záujmov bola na začiatku konštitučným prvkov vzniku vzt’ahu. Možno predpokladat' že áno. V tom prípade je potrebné hl'adat' latentné štruktúry, ktoré spôsobili zmenu v názore a prehodnotenie týchto konštitučných prvkov. No taktiež všeobecné hodnotenie rozpadu vzt'ahu môže byt' prijatel’nejšou alternatívou, ktorú rozchádzajúci sa partneri prezentujú širšiemu okoliu a svojim det'om (v prípade, že deti majú) a kamuflujú tak ukryté traumy, ktoré partnerský vzt’ah mohol prinášat'.

16 Pre vývoj úhrnnej rozvodovosti pozri stránky Statistického úřadu České republiky: $<$ http://czso.cz/ $\mathrm{csu}>$

17 Počet detí narodených mimo manželstva v posledných rokoch výrazne stúpol. Slobodné matky, ktoré privádzajú diet’a na svet, tak robia aj napriek všeobecne prijatému mediálnemu diskurzu o ,zodpovednom rodičovstve“. Podl'a Statistického úřadu České republiky ale nie je úplne možné jednoznačne určit', kol'ko z nemanželsky narodených detí sa rodí do fungujúcej, hoci neoddanej rodiny, a kol'ko pripadá na matky samo-živitel'ky. Nápomocne v tomto prípade môže slúžit' údaj o otcovi, ktorý štatistika sleduje aj u nemanželských detí od roku 2007, pretože je tu predpoklad, že matky, ktoré pri pôrode neuviedli údaj o otcovi diet'at'a, sa budú starat' o diet’a samé, čo z údajov z roku 2008 naznačuje, že do neúplnej rodiny sa narodilo každé desiate diet’a. Bližšie pozri $V y ́ v o j$ obyvatelstva v České republiky v roce 2008. Dostupne online na $<\mathrm{http}: / / \mathrm{czso} . c \mathrm{cz} / \mathrm{csu}>$

18 Bližšie k štatistike príčin rozvratu manželstva Vývoj obyvatelstva České republiky v roce 2008. Dostupné on-line na $<$ http://czso.cz/csu $>$ 
Samozrejme otázna je aj váha, ktorá je v rodinnom diskurze prikladaná partnerským vzt'ahom v manželstve a rodičovstve (vid' vyššie, Giddens 1992). Zadné dvierka vyviazania sa z manželstva už nie sú len pootvorené, vedomost' o ich existencii je prítomná už v samotnom začiatku vzt’ahu a je reprodukovaná v kultúre spoločnosti. Čo sa samozrejme prenáša aj do vzt'ahu k diet'at'u/det'om a do rodičovskej (najmä otcovskej) zodpovednosti; tá je v prípade otcov obmedzená ešte neistotou mužov, že svoje deti budú môct' vychovávat' (Možný 2008). Bariéry otcovských tranzícií sú preto zakorenené už v základoch rodiny. To, či sa im podarí vyklíčit', záleží od ne/úspechu partnerského vyjednávania, schopnosti čelit’ vonkajším tlakom a ochoty podiel'at' sa na rodičovstve. Problematika bariér otcovských tranzícií tak ostáva výzvou nielen pre výskum, ale aj teoretické ukotvenie otcovstva.

\section{Literatúra}

ARENDELL, Terry. Fathers \& Divorce. Thousand Oaks: SAGE Publications, 1995. 303 s. ISBN 0803971893.

ARIES, Philippe. Centuries of Childhood. A Social History of Family Life. New York: Vintage Books, 1962. 447 s. ISBN 0394702867.

BARTOŠOVÁ, Michaela. Ženy po třicítce - př́iklad specifických reprodukčních strategií a jejich zdrojů. Sociologický časopis $A V \check{C} R, 2009$, roč. 45, č. 1, s. 147-176. ISSN 0038-0288.

BECK, Ulrich. Riziková společnost: Na ceste k jiné moderně. Praha: Sociologické nakladatelství, 2004. 431 s. ISBN 8086429326.

BECK-GERNSHEIM, Elisabeth. Reinventing the Family: In Search of New Lifestyles. Cambridge: Polity Press, 2002. 170 s. ISBN 0745622143.

BOURDIEU, Pierre. Teorie jednání. Praha: Karolinum, 1998. 179 s. ISBN 8071845183.

BOURDIEU, Pierre. Nadvláda mužů. Praha: Karolinum, 2000. 145 s. ISBN 8071847755.

CABRERA, Natasha J. a kol. Fatherhood in the Twenty-First Century. Child Development, 2000, roč. 71, č. 1 , s. $127-136$.

ČERNÁ, Marie. Rozvod, otcové a děti. Praha: Eurolex Bohemia, 2001. 114 s. ISBN 8086432114.

DALY, Kerry J. Reshaping Fatherhood: Finding the Models. In MARSIGLIO, W. (ed.) Fatherhood: Contemporary Theory, Research, and Social Policy. Thousand Oaks: SAGE Publications, 1995. $320 \mathrm{~s}$.

DERMOTT, Esther. Intimate Fatherhood. A Sociological Analysis. London, New York: Routledge, 2008. 170 s. ISBN 9780415422628.

DEVAULT, Annie a kol. Life Stories of Young Fathers in Contexts of Vulnerability. Fathering, 2008, roč. 6, č. 3, s. 226-248. ISSN 1537-6680.

DINNERSTEIN, Dorothy. The Mermaid and The Minotaur: Sexual Arrangements and Human Malaise. New York: Other Press, 1999. 295 s. ISBN 1892746255.

DUDOVÁ, Radka. Otcovství po rozchodu rodičovského páru. Praha: Sociologický ústav AV ČR, 2008. 234 s. ISBN 9788073301361.

DOWD, Nancy. E. Redefining Fatherhood. New York, London: New York University Press, 2000. 292 s. ISBN 9780814719251.

ERIKSON, Erik. H. Dětství a společnost. Praha: Argo, 2002. 387 s. ISBN 8072033808.

FORSTE, Renata; BARTKOWSKI, John. P.; JACKSON, Rebecca Allen. Just Be There for Them: Perceptions of Fathering Among Single, Low-Income Men. Fathering, 2009, roč. 7, č. 1, s. 49-69. ISSN 1537-6680. 
FURSTENBERG, Frank. F., Jr. Fathering in the Inner City: Paternal Participation and Public Policy. In MARSIGLIO, W. (ed.) Fatherhood: Contemporary Theory, Research, and Social Policy. Thousand Oaks: SAGE Publications, 1995. 320 s. ISBN 0-8039-5783-1.

GEIGER, Brenda. Fathers as Primary Caregivers. Westport: Greenwood Press, 1996. 143 s. ISBN 0313299196.

GIDDENS, Anthony. Modernity and Self-Identity: Self and Society in the Late Modern Age. Cambridge: Polity Press, 1991. 256 s. ISBN 0745609325.

GIDDENS, Anthony. The Transformation of Intimacy: Sexuality, Love and Eroticism in Modern Societies. Cambridge: Polity Press, 1992. 212 s. ISBN 0745610129.

HASMANOVÁ MARHÁNKOVÁ, Jaroslava. Těhotenství v perspektivě sociálních věd. Sociálni studia, 2009, roč. 6, č. 4, s. 55-71. ISSN 1214-813X.

HAŠKOVÁ, Hana. Fenomén bezdětnosti. Praha: Sociologické nakladatelství, 2009. 264 s. ISBN 9788074190209.

HOBSON, Barbara (ed.). Making Men into Fathers: Men, Masculinities and the Social Politics of Fatherhood. Cambridge: Cambridge University Press, 2002. 328 s. ISBN 0521006120.

HOBSON, Barbara; MORGAN, David. Introduction. In HOBSON, B. (ed.) Making Men into Fathers: Men, Masculinities and the Social Politics of Fatherhood. Cambridge: Cambridge University Press, 2002, s. 1-21. ISBN 0521006120.

CHORVÁT, Ivan. Muž - otec v súčasnej rodine. Banská Bystrica: Ekonomická fakulta UMB, 1999. ISBN 8080552711.

JAMIESON, Lynn. Intimacy. Personal Relationships in Modern Society. Cambridge: Polity Press, 1998. 209 s. ISBN 0745615740.

KELLER, Jan. Nedomyšlená společnost. Brno: Doplněk, 1992. 125 s. ISBN 8090110207.

LA ROSSA, Ralph. The Modernization of Fatherhood. Chicago: The University of Chicago Press, 1997. ISBN 0226469034.

LUPTON, Deborah; BARCLAY, Lesley. Constructing Fatherhood: Discourses and Experiences. London: SAGE Publications, 1997. 176 s. ISBN 076195340X.

MARKS, Loren, PALKOVITZ, Rob. American Fatherhood Types: The Good, the Bad, and the Uninterested. Fathering, 2004, roč. 2, č. 2, s. 113-129. ISSN 1537-6680.

MARSIGLIO, William (ed.). Fatherhood: Contemporary Theory, Research, and Social Policy. London: SAGE Publications. 1995. 320 s. ISBN 0-8039-5783-1.

MARSIGLIO, William. Stepdads: Stories of Love, Hope, and Repair. Lanham, MD: Rowman \& Littlefield, 2004. 319 s. ISBN 0742526739.

McQUAIL, Dennis. Úvod do teorie masové komunikace. Praha: Portál, 2007. 447 s. ISBN 9788073673383.

MOŽNÝ, Ivo. Declining Fertility in Europe and What Paretnhood Means to Czechs. Brno: Masaryk University, 2008. 132 s. ISBN 9788021045545.

MOŽNÝ, Ivo. Moderní rodina: mýty a skutečnosti. Brno: Blok, 1990. 184 s. ISBN 8070290188.

MOŽNÝ, Ivo. Rodina vysokoškolsky vzdělaných manželi̊. Brno: Univerzita J. E. Purkyně v Brně, 1983. $189 \mathrm{~s}$.

NOCK, Steven. L. Marriage in Men's Lives. Oxford: Oxford University Press, 1998. 165 s. ISBN 0195120566.

PALKOVITZ, Rob; PALM, Glen. Transitions within Fathering. Fathering, 2009, roč. 7, č. 1, s. 3-22. ISSN 1537-6680.

POTANČOK, Juraj. Zmeny v chápaní úlohy otca v súčasnej rodine: zaostrené na typológiu. Sociológia Slovak Sociological Review, 2010, roč. 42, č. 2, s. 113-133. ISSN 0049-1225. 2010.

RABUŠIC, Ladislav. Kde ty všechny děti jsou? Porodnost v sociologické perspektivě. Praha: Sociologické nakladatelství, 2001. 265 s. ISBN 8086429016.

SINGLY, François de. Sociologie současné rodiny. Praha: Portál, 1999. 127 s. ISBN 8071782491. 
SINGLY, François de. Mít vlastní pokoj. Ke vztahu mezi prostorem a osobní identitou. Sociální studia, 2009, č. 4, s. 13-22. ISSN 1214-813X.

SKUPNIK, Jaroslav. Antropologie přibuzenství. Př́buzenství, manželství a rodina v kulturně antropologické perspektivě. Praha: Sociologické nakladatelství, 2010. 402 s. ISBN 9788074190193.

SLEPIČKOVÁ, Lenka. Neplodnost jeho a neplodnost její: Genderové aspekty asistované reprodukce. Sociologický časopis $A V \check{C} R, 2009$, roč. 45, č. 1, s. 177-203. ISSN 0038-0288.

SLEPIČKOVÁ, Lenka. Couples Undergoing Infertility Treatment in the Czech Republic: Broad Range of Possibilities in a Traditional Milieu. Social Theory and Health, 2010, roč. 8, č. 2, s. 151-174.

SLEPIČKOVÁ, Lenka; FUČÍK, Petr. Sociální kontext postojů k řešení neplodnosti. Sociologický časopis $A V \check{C} R, 2009$, roč. 45, č. 2, s. 267-290. ISSN 0038-0288.

SMART, Carol; NEALE, Bren. Family Fragments? Malden: Polity Press, 1999. 222 s. ISBN 0745618936.

ŠMÍDOVÁ, Iva. Matkové. In MAREŠ, P.; POTOČNÝ, T. (eds.) Modernizace a česká rodina. Brno: Barrister \& Principal, 2003, s. 157-175. ISBN 8086598616.

TOMÁŠEK, Marcel. Singles a jejich vztahy; kvalitativní pohled na nesezdané a nekohabitující jednotlivce v České republice. Sociologický časopis $A V C \check{C} R$, 2006, roč. 42, č. 1, s. 81-105. ISSN 0038-0288.

TOMÁŠEK, Marcel. K genderovým zdrojům individualizačního habitu. Gender, rovné př́ležitosti, výzkum, 2006, roč. 7, č. 1, s. 75-81. ISSN 1211-5770.

TOMÁŠEK, Marcel. Normativní normalizace? Biograf, 2007, č. 43-44, s. 121-131. ISSN 1212-0028.

TOWNSEND, Nicholas W. The Package Deal: Marriage, Work, and Fatherhood in Men's Lives. Philadelphia: Temple University Press, 2002. 248 s. ISBN 1566399580.

\section{Autor}

Juraj Potančok študoval odbor sociológia na Fakulte humanistiky Trnavskej univerzity v Trnave. Od roku 2008 je doktorandským študentom sociológie na Fakulte sociálních studií Masarykovej univerzity v Brne. Vo výskume v rámci dizertačnej práce sa zaoberá sociológiou rodiny, konkrétne otcovstvom.

Kontakt: juraj.potancok@gmail.com 